\title{
The study of the qualitative and quantitative content of the amount of flavonoids and hydroxycinnamic acids in a dense extract of common tansy flowers
}

In recent years, herbal medicines have become increasingly popular in the pharmacotherapy of many diseases. One of the medicinal plants widely distributed in the wild on the territory of Ukraine is common tansy (Tanacetum vulgare L.) of the Asteraceae family; it is a promising raw material for the development of new medicines. In this regard, it is relevant to study and standardize a dense extract of common tansy flowers (DECTF) to predict the possible pharmacological action and the feasibility of further use in the production of solid dosage forms.

Aim. To study the qualitative and quantitative content of the amount of flavonoids and the amount of hydroxycinnamic acids in a dense extract of common tansy flowers.

Materials and methods. The study object was DECTF. The qualitative composition of phenolic compounds in the extract was determined by TLC. The quantitative determination of the amount of flavonoids calculated with reference to luteolin was performed by the spectrophotometric method.

Results and discussion. The identification of DECTF was performed by TLC. It allowed us to identify 3 dominant compounds of phenolic nature - luteolin, luteolin-7-glycoside and chlorogenic acid. The quantitative content of phenolic substances in DECTF was studied by spectrophotometry; it was found that the amount of flavonoids (calculated with reference to luteolin) was $3.69 \pm 0.01 \%$; the amount of hydroxycinnamic acids (calculated with reference to chlorogenic acid) was $16.88 \pm 0.02 \%$.

Conclusions. A significant content of flavonoids and hydroxycinnamic acids in DECTF indicates the prospects for further research and development of new drugs with the anti-inflammatory, antimicrobial and choleretic action based on it.

Key words: TLC; spectrophotometry; dense extract; common tansy; luteolin; hydroxycinnamic acids

\author{
Н. А. Гербіна, О. А. Рубан, Т. М. Гонтова, М. С. Яременко, К. Ю. Юрченко \\ Національний фармацевтичний університет Міністерства охорони здоров'я України
}

Дослідження якісного та кількісного вмісту суми флавоноїдів та гідроксикоричних кислот у густому екстракті квіток пижма звичайного

Останнім часом лікарські засоби рослинного походження набувають дедалі більшої популярності у фрармакотерапії багатьох захворювань. Однією з лікарських рослин, широко розповсюджених у дикому вигляді на території України, є пижмо звичайне (Tanacetum vulgare L.) родини Айстрові (Asteraceae), яка є перспективною сировиною для розроблення нових лікарських засобів. 3 огляду на це актуальним постає дослідження та стандартизація густого екстракту квіток пижма звичайного (ГЕКПЗ) для прогнозування можливої фармакологічної дії та доцільності подальшого використання у виробництві твердих дозованих лікарських форм.

Мета роботи. Дослідити якісний і кількісний вміст суми флавоноїдів та суми гідроксикоричних кислот у густому екстракті квіток пижма звичайного.

Матеріали та методи. Об'єктом дослідження був ГЕКПЗ. Визначення якісного складу френольних сполук у екстракті проводили методом ТШХ, а кількісне визначення суми фрлавоноїдів у перерахунку на лютеолін - спектрофотометричним методом.

Результати та їх обговорення. Проведено ідентифікацію ГЕКПЗ методом ТШХ, яка дозволила виявити 3 домінувальні сполуки френольної природи - лютеолін, лютеолін-7-глікозид та хлорогенову кислоту. Досліджено кількісний вміст френольних речовин у ГЕКПЗ методом спектрофотометрії та визначено, що сума флавоноїдів (у перерахунку на лютеолін) становила 3,69 \pm 0,01 \%; вміст суми гідроксикоричних кислот (у перерахунку на хлорогенову кислоту) $-16,88 \pm 0,02 \%$.

Висновки. Значний вміст фрлавоноїдів і гідроксикоричних кислот у ГЕКПЗ доводить перспективність проведення подальших досліджень і розроблення нових лікарських препаратів протизапальної, антимікробної та жовчогінної дії на його основі.

Ключові слова: ТШХ; спектрофротометрія; густий екстракт; пижмо звичайне; лютеолін; оксикоричні кислоти 


\section{Н. А. Гербина, Е. А. Рубан, Т. Н. Гонтовая, М. С. Яременко, Е. Ю. Юрченко \\ Национальный фрармацевтический университет Министерства здравоохранения Украины \\ Исследование качественного и количественного содержания суммы флавоноидов и гидроксикоричных кислот в густом экстракте цветков пижмы обыкновенной}

В последние годы лекарственные средства растительного происхождения приобретают все большую популярность в фрармакотерапии многих заболеваний. Одним из лекарственных растений, широко распространённым в диком виде на территории Украины, является пижма обыкновенная (Tanacetum vulgare L.) семейства Астровые (Asteraceae), которая представляется перспективным сырьем для разработки новых лекарственных средств. В связи с этим актуальным является исследование и стандартизация густого экстракта цветков пижмы обыкновенной (ГЭЦПО) для прогнозирования возможного фрармакологического действия и целесообразности дальнейшего использования в производстве твердых дозированных лекарственных форм.

Цель работы - исследовать качественное и количественное содержание суммы флавоноидов и суммы гидроксикоричных кислот в густом экстракте цветков пижмы обыкновенной.

Материалы и методы. Объектом исследования был ГЭЦПО. Определение качественного состава фенольных соединений в экстракте проводили методом ТCX, а количественное определение суммы фллавоноидов в пересчете на лютеолин - спектрофотометрическим методом.

Результаты и их обсуждение. Проведена идентификация ГЭЦПО методом ТСХ, которая позволила определить 3 доминирующие соединения фенольной природы - лютеолин, лютеолин-7-гликозид и хлорогеновую кислоту. Исследовано количественное содержание фенольных веществ в ГЭЦПО методом спектрофотометрии и установлено, что сумма фрлавоноидов (в пересчете на лютеолин) составляла 3,69 \pm 0,01\%; содержание суммы гидроксикоричных кислот (в пересчете на хлорогеновую кислоту) - 16,88 \pm 0,02\%.

Выводы. Значительное содержание флавоноидов и гидроксикоричных кислот в ГЭЦПО указывает на перспективность проведения дальнейших исследований и разработки новых лекарственных препаратов противовоспалительного, антимикробного и желчегонного действия на его основе.

Ключевые слова: ТСХ; спектрофотометрия; густой экстракт; пижма обыкновенная; лютеолин; оксикоричные кислоты

Introduction. In recent years, herbal medicines have become increasingly popular in the pharmacotherapy of many diseases. According to the WHO statistics, up to $80 \%$ of the world's population prefers drugs of natural origin. Interest in the use of medicinal plants and medicines obtained on their basis is due to their low toxicity in most cases, and therefore, the possibility of the longterm use (months, years), as well as a complex effect on the human body. The role of herbal medicines in chronic diseases where they can be used as the maintenance therapy between courses of the main treatment is increasing. They are used in the prevention of diseases since the complex of biologically active substances (BAS) of plants has a greater affinity with the human body than isolated chemically pure active substances that determine the polyvalence of pharmacological properties, and simultaneously it safely affects various body systems involved in the pathological process [1].

In addition, an important prerequisite for creating herbal medicines is the availability of the raw material and the possibility of cultivating species, control of BAS accumulation by plant vegetation phases during the raw material harvesting [2].

One of the medicinal plants widely distributed in the wild on the territory of Ukraine is common tansy (Tanacetum vulgare L.) of the Asteraceae family. The main groups of BAS of this type are flavonoids, hydroxycinnamic acids, volatile components of essential oil $\alpha$ - and $\beta$-thujone, and others. Common tansy has the choleretic, antimicrobial, anthelmintic, phytoncidal, antiinflammatory, antispasmodic effects and is mainly used to treat diseases of the liver, gallbladder, gastrointestinal tract, and as an anthelmintic agent [3-6].
At the pharmaceutical market of Ukraine there are only two medicines based on common tansy: the medicinal plant raw material "Tansy flowers" in packs and the herbal tea "Fitohepatol" in sachets produced by PJSC Lectravy". Therefore, the development of new medicinal herbal medicines based on it is a promising direction $[7-8]$.

In this regard, it is relevant to study and standardize a dense extract of common tansy flowers (DECTF) in order to predict the possible pharmacological action and the feasibility of further use in the production of solid dosage forms.

The aim of this work was to study the qualitative and quantitative content of the amount of flavonoids and the amount of hydroxycinnamic acids in a dense extract of common tansy flowers.

Materials and methods. The study object was DECTF obtained at the premises of the Department of Botany, National University of Pharmacy. Tansy flowers were crushed to a particle size of 2-3 $\mathrm{mm}$ and extracted three times with $70 \%$ water-ethanol solution. The ratio of the mass of the raw material to the total volume of the extractant was $1: 5$. The resulting extracts were combined and allowed to stand for 24 hours at a temperature of $2-4{ }^{\circ} \mathrm{C}$, after that they were filtered and evaporated on a rotary vacuum evaporator until a thick mass with humidity of not more than $25 \%$ was obtained.

The dense extract obtained was a viscous mass of a dark brown color with a specific odor; it stretched into threads and again mixed into a solid mass.

The qualitative composition of phenolic compounds in the extract was determined by TLC, taking as a basis the unified TLC methodology presented in monograph 


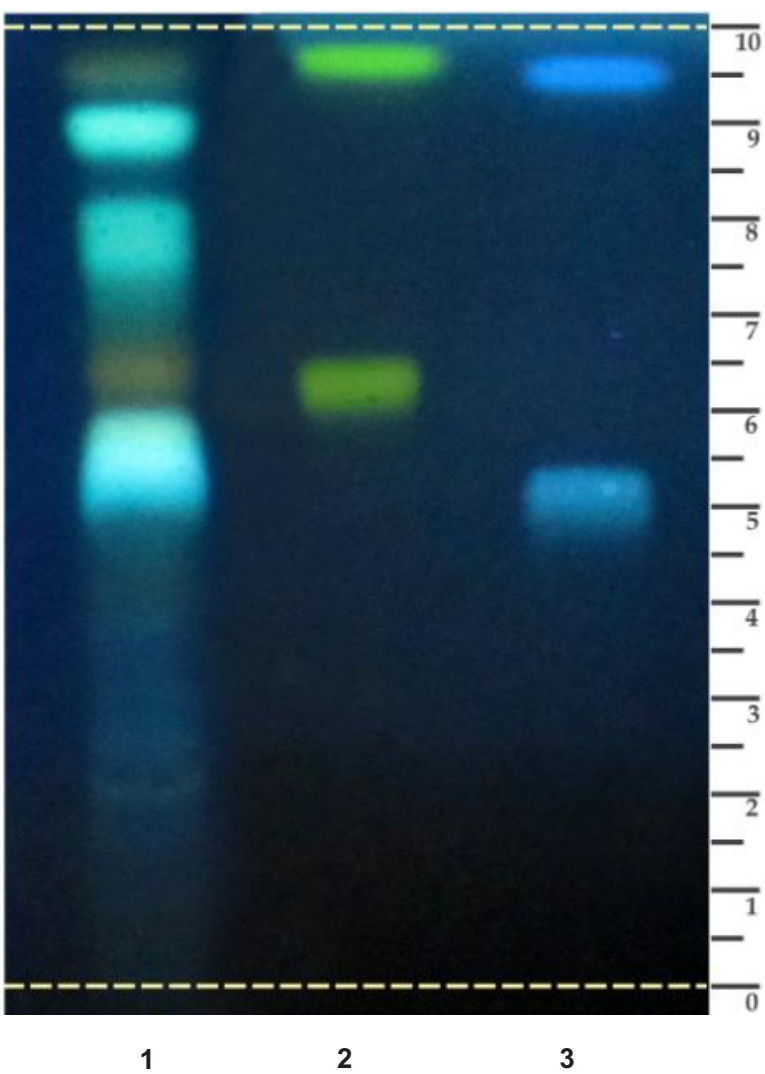

Fig. 1. The chromatogram of the extract and $R S$ (SPhU)

Note. 1 - the solution of the extract; $R S$ (SPhU): 2 - chlorogenic and caffeic acids; 3 - luteolin and luteolin-7-glycoside.

of the State Pharmacopoeia of Ukraine (SPhU) Ed. 2 Suppl. 2 "Tansy flowers ${ }^{\mathrm{N}}$ " [9, 10] Luteolin, luteolin7-glycoside, chlorogenic and caffeic acids were selected as standard marker substances.

Test solution. For its preparation, dissolve the extract in the amount of $0.5 \mathrm{~g}$ in $10 \mathrm{ml}$ of methanol when heated on a water bath at the temperature of $60^{\circ} \mathrm{C}$ under reflux for $10 \mathrm{~min}$, then cool and filter.

Reference solutions. Use the official reference standards $(R S)$ of the SPhU - 2.5 mg of luteolin, $2.5 \mathrm{mg}$ of lueolin-7-glycoside, $2.5 \mathrm{mg}$ of chlorogenic acid, $2.5 \mathrm{mg}$ of caffeic acid in $10 \mathrm{ml}$ of methanol.

Plate. TLC plates with a silica gel 60 layer.

Mobile phase. Anhydrous formic acid RS-purified water $R S$ - methylethylketone $R S$ - ethyl acetate $R S$ in the ratio of $(10: 10: 30: 50)$.

Injection volume. Apply $10 \mu \mathrm{L}$ of each solution in strips.

Distance that the mobile phase must pass. $10 \mathrm{~cm}$ from the start line.

Detection. Detect after drying at a temperature of $100-105^{\circ} \mathrm{C}$ for $5 \mathrm{~min}$. Treat a warm plate with the solution of $10 \mathrm{~g} / \mathrm{L}$ aminoethyl ether of diphenylboric acid $R S$ in methanol $R S$ and the solution of $50 \mathrm{~g} / \mathrm{L}$ macrogol $R S 400$ in methanol $R S$. Evaluate the results after drying in the air for $30 \mathrm{~min}$ and examine in the UV light at a wavelength of $365 \mathrm{~nm}$ (Fig. 1).

The quantitative determination of the amount of flavonoids calculated with reference to luteolin was performed by the unified spectrophotometric method described in the monograph of the SPhU Ed. 2 Suppl. 2
"Tansy flowers ${ }^{\mathrm{N} "}$ using a HP-8453 UV-VIS spectrophotometer [9, 11].

Stock solution 1. Collect $0.16 \mathrm{~g}$ of a dense extract in a $100 \mathrm{ml}$ flask and dilute to the volume with the same solvent ( $70 \%$ ethanol). Then the study is carried out according to the method.

Test solution 1. Place $5.0 \mathrm{ml}$ of Stock solution 1 in a round-bottomed flask and evaporate to dryness under reduced pressure. Transfer the resulting residue to a $25 \mathrm{ml}$ volumetric flask using $8 \mathrm{ml}$ of the mixture of methanol $R S$ - anhydrous acetic acid $R S(10: 100)$. Rinse a roundbottomed flask with $3 \mathrm{ml}$ of the mixture of methanol $R S$ - anhydrous acetic acid $R S$ (10:100), and place the washing liquid in the same $25 \mathrm{ml}$ volumetric flask. Add $10.0 \mathrm{ml}$ of the solution containing $25.0 \mathrm{~g} / \mathrm{L}$ of boric acid $R S, 20.0 \mathrm{~g} / \mathrm{L}$ of oxalic acid $R S$ in anhydrous formic acid $R S$ to the solution obtained, and dilute the solution to $25.0 \mathrm{ml}$ with anhydrous acetic acid $R S$.

Compensation solution 1. Place $5.0 \mathrm{ml}$ of Stock solution 1 in a round-bottomed flask and evaporate to dryness under reduced pressure. Transfer the resulting residue to a $25 \mathrm{ml}$ volumetric flask using $8 \mathrm{ml}$ of the mixture of methanol RS-anhydrous acetic acid RS (10:100). Rinse a round-bottomed flask with $3 \mathrm{ml}$ of the mixture of methanol $R S$ - anhydrous acetic acid $R S$ (10:100), and place the washing liquid in the same $25 \mathrm{ml}$ volumetric flask. Add $10.0 \mathrm{ml}$ of anhydrous formic acid $R S$ to the solution obtained, and dilute the solution to $25.0 \mathrm{ml}$ with anhydrous acetic acid RS.

Stock solution 2. Place approximately $0.010 \mathrm{~g}$ (accurate weight) of luteolin $R S$ (SPhU) in a $100 \mathrm{ml}$ volumetric flask, dissolve in $70 \mathrm{ml}$ of methanol $R S$, dilute the solution to the volume with the same solvent and mix.

Reference solution. Transfer $1.0 \mathrm{ml}$ of Stock solution 2 to a $25 \mathrm{ml}$ volumetric flask. Add $10.0 \mathrm{ml}$ of the solution containing $25.0 \mathrm{~g} / \mathrm{L}$ of boric acid $R S, 20.0 \mathrm{~g} / \mathrm{L}$ of oxalic acid $R S$ in anhydrous formic acid $R S$ and dilute the solution to $25.0 \mathrm{ml}$ with anhydrous acetic acid $R S$.

Compensation solution 2. Transfer $1.0 \mathrm{ml}$ of Stock solution 2 to a $25 \mathrm{ml}$ volumetric flask, add $10.0 \mathrm{ml}$ of anhydrous formic acid $R S$, and dilute the solution to $25.0 \mathrm{ml}$ with anhydrous acetic acid $R S$.

The optical density of Test solution was measured $30 \mathrm{~min}$ after the preparation at a wavelength of $410 \mathrm{~nm}$ in relation to Compensation solution 1. In parallel, the optical density of Reference solution in relation Compensation solution 2 was measured.

The content of the amount of flavonoids calculated with reference to luteolin in a dense extract was calculated by the formula:

$$
\mathrm{X}, \%=\frac{A_{1} \times m_{0} \times 20 \times \mathrm{P} \times 100 \%}{A_{0} \times m \times(100-w) \times 100},
$$

where: $A_{1}$ - is the optical density of Test solution at a wavelength of $410 \mathrm{~nm} ; A_{0}$ - is the optical density of Reference solution at a wavelength of $410 \mathrm{~nm} ; m_{0}$ - is the sample weight of luteolin $R S$ (SPhU), g; $m$ - is the sample weight of the raw material tested, $\mathrm{g} ; P$ - is the luteolin content in luteolin $R S(\mathrm{SPhU}), \% ; w-$ is the loss of the raw material on drying, $\%$. 


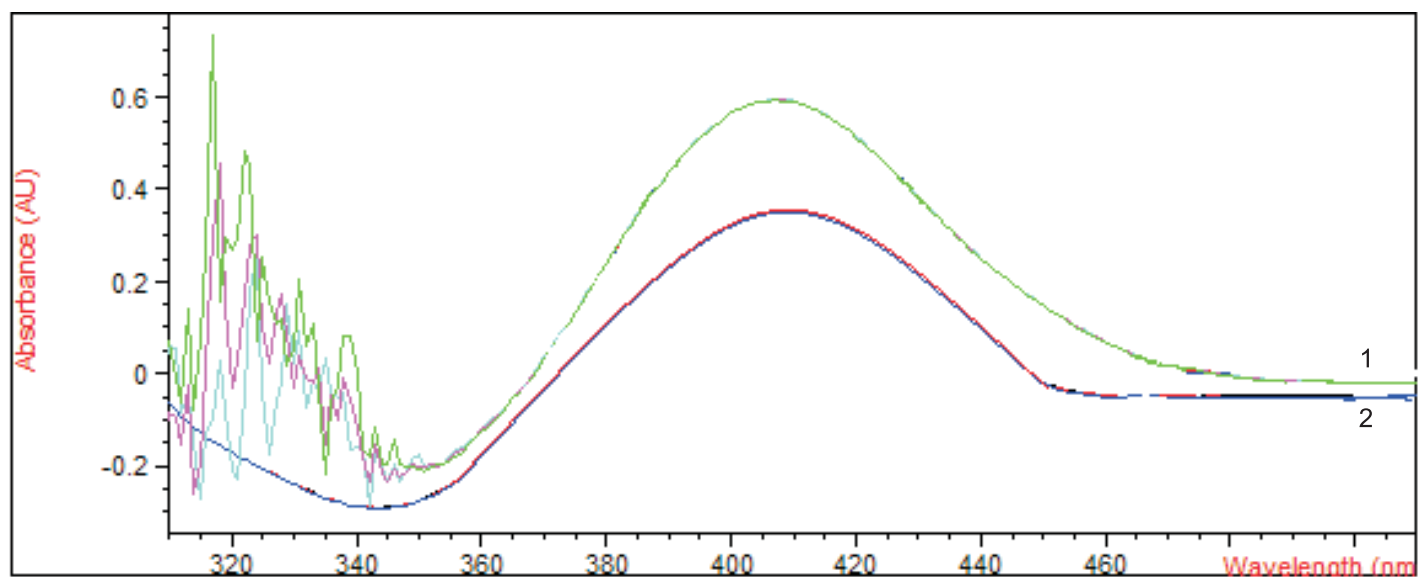

Fig. 2. The typical absorption spectra of the test solution of DECTF (1) and the reference solution (2)

The quantitative content of the amount of hydroxycinnamic acids in DECTF was determined by the spectrophotometric method calculated with reference to chlorogenic acid described in the monograph of the SPhU 2.3 "Nettle leaves".

Stock solution. Place $0.16 \mathrm{~g}$ of a dense extract in a $100 \mathrm{ml}$ volumetric flask and dilute to the volume with $70 \%$ ethanol.

Test solution. Place $1 \mathrm{ml}$ of Stock solution to a $10 \mathrm{ml}$ volumetric flask, successively add $2 \mathrm{ml}$ of $0.5 \mathrm{M}$ hydrochloric acid solution, $2 \mathrm{ml}$ of a freshly prepared solution of $10 \mathrm{~g}$ of sodium nitrite $R S$ and $10 \mathrm{~g}$ of sodium molybdate in $100 \mathrm{ml}$ of water $R S$ and $2 \mathrm{ml}$ of diluted sodium hydroxide solution $R S$ stirring after each addition, dilute to the volume with water $R S$ and mix.

Compensation solution. Place $1 \mathrm{ml}$ of Stock solution to a $10 \mathrm{ml}$ volumetric flask, successively add $2 \mathrm{ml}$ of $0.5 \mathrm{M}$ hydrochloric acid solution and $2 \mathrm{ml}$ of diluted sodium hydroxide solution $R S$ stirring after each addition, dilute to the volume with water $R S$ and mix.

The optical density of Test solution was measured immediately at a wavelength of $525 \mathrm{~nm}$ in a cuvette with the layer thickness of $10 \mathrm{~mm}$, using Compensation solution as a reference solution.

The content of the amount of hydroxycinnamic acids calculated with reference to chlorogenic acid (\%) in a dense extract was calculated by the formula:

$$
\mathrm{X}=\frac{A_{1} \times 1000 \times 100}{188 \times m \times(100-W)},
$$

where: $A$ - is the optical density of Test solution at a wavelength of $525 \mathrm{~nm} ; W-$ is the loss of the raw material on drying, \%; $m$ - is the sample weight of the raw material tested, $g$.
For the calculation, the specific absorption index of chlorogenic acid equal to 188 was used.

Results and discussion. The identification of the DECTF sample studied was performed compared to the selected $R S(\mathrm{SPhU})$ on a single chromatographic plate under the conditions of the method. For this purpose, the selected $R S$ $(\mathrm{SPhU})$ of luteolin, luteolin-7-glycoside, chlorogenic and caffeic acids were applied to the chromatographic plate in parallel with the samples of the DECTF studied. The chromatography results obtained were described in relation to the selected $R S$ : color, color intensity, location on the plate. The results are shown in Fig. 1.

On the chromatogram of the DECTF solution, 6 zones were observed; of them, the yellow and yellowish-brown fluorescence zones corresponded to the zones of reference solutions of luteolin and luteolin-7-glycoside. Below these zones there was a blue fluorescence zone, which corresponded to the zone of the reference solution of chlorogenic acid. The results of the study indicate the presence of the substances studied in DECTF.

Therefore, the next step was to determine the quantitative content of luteolin and chlorogenic acid in DECTF. It was found that the content of the amount of flavonoids mainly represented by flavones calculated with reference to luteolin reached $3.69 \pm 0.01 \%$ (Fig. 2, Tab.1).

Metrological characteristics are given in Tab. 1.

The unified spectrophotometric method selected for determination of the amount of hydroxycinnamic acids is acceptable for the raw material studied; it is confirmed by the UV spectrum of the amount of hydroxycinnamic acids obtained in DECTF (Fig. 3).

The content of the amount of hydroxycinnamic acids was at the level of $16.88 \pm 0.02 \%$ calculated with reference to chlorogenic acid.

Table 1

Metrological characteristics for determining the quantitative content of flavonoids in DECTF

\begin{tabular}{|c|c|c|c|c|c|c|c|c|c|}
\hline $\mathrm{m}$ & $\mathrm{n}$ & $\mathrm{X}_{\mathrm{i}}$ & $\mathrm{X}_{\mathrm{av}}$ & $\mathrm{S}^{2}$ & $\mathrm{~S}_{\mathrm{av}}$ & $\mathrm{P}$ & $\mathrm{t}(\mathrm{P}, \mathrm{n})$ & $\begin{array}{c}\text { Confidence } \\
\text { interval }\end{array}$ & $\varepsilon_{-} \%$ \\
\hline \multirow{2}{*}{3} & \multirow{2}{*}{2} & 3.69 & \multirow{2}{*}{3.6867} & 0.000033 & 0.0033 & 0.95 & 2.78 & $3.69 \pm 0.01$ & 0.25 \\
\cline { 6 - 10 } & 3.68 & 3.69 & & & & & & \\
\cline { 5 - 10 }
\end{tabular}




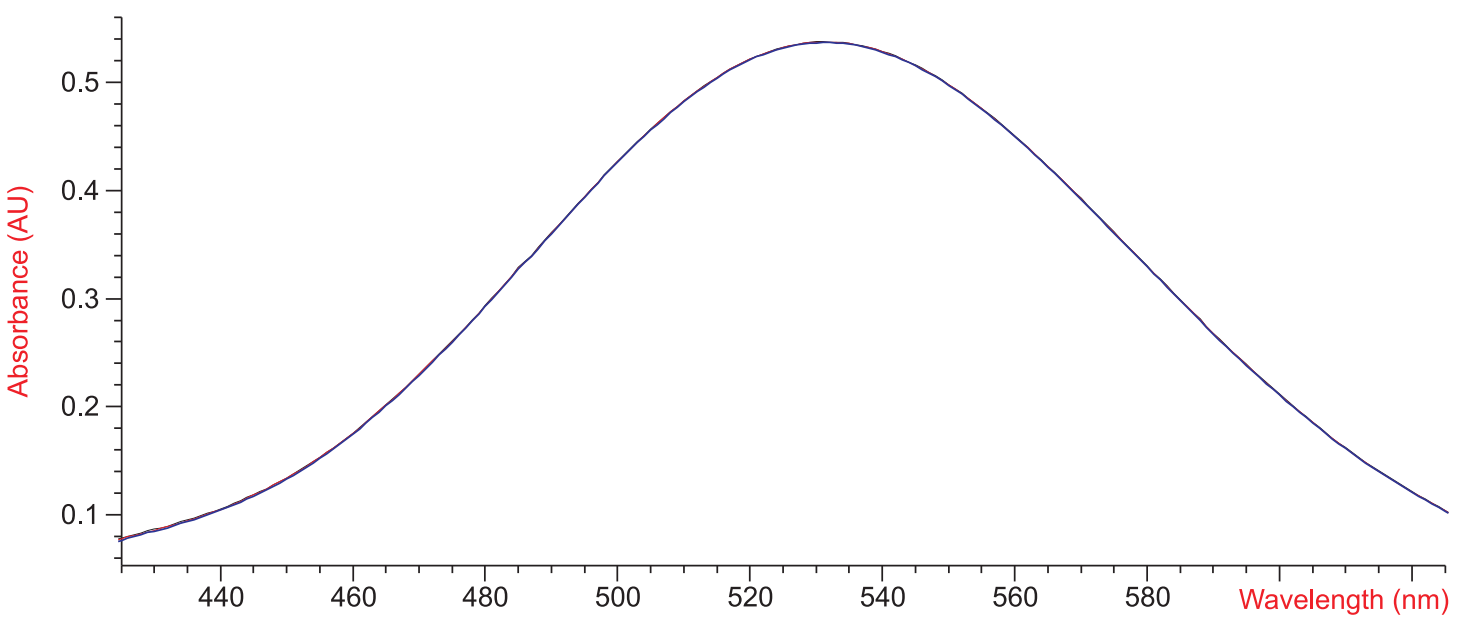

Fig. 3. The typical absorption spectra of the test solution of DECTF when determining the quantitative content of the amount of hydroxycinnamic acids

Table 2

Metrological characteristics for determining the quantitative content of hydroxycinnamic acids in DECTF

\begin{tabular}{|c|c|c|c|c|c|c|c|c|c|}
\hline $\mathrm{m}$ & $n$ & $X_{i}$ & $X_{a v}$ & $S^{2}$ & $\mathrm{~S}_{\mathrm{av}}$ & P & $t(P, n)$ & $\begin{array}{c}\text { Confidence } \\
\text { interval }\end{array}$ & $\varepsilon_{-} \%$ \\
\hline \multirow{3}{*}{3} & \multirow{3}{*}{2} & 16.88 & \multirow{3}{*}{16.8833} & \multirow{3}{*}{0.0002} & \multirow{3}{*}{0.0088} & \multirow{3}{*}{0.95} & \multirow{3}{*}{2.78} & \multirow{3}{*}{$16.88 \pm 0.02$} & \multirow{3}{*}{0.15} \\
\hline & & 16.90 & & & & & & & \\
\hline & & 16.87 & & & & & & & \\
\hline
\end{tabular}

Metrological characteristics for determining the quantitative content of hydroxycinnamic acids in DECTF are given in Tab. 2.

\section{Conclusions and prospects of further research}

1. The identification of DECTF has been performed by TLC. It has allowed us to identify 3 dominant compounds of phenolic nature - luteolin, luteolin-7glycoside and chlorogenic acid.

2. The quantitative content of phenolic substances in DECTF has been studied by spectrophotometry; it has been found that the amount of flavonoids (calculated with reference to luteolin) is $3.69 \pm 0.01 \%$; the amount of hydroxycinnamic acids (calculated with reference to chlorogenic acid) is $16.88 \pm 0.02 \%$.

3. A significant content of flavonoids and hydroxycinnamic acids in DECTF indicates the prospects for further research and development of new drugs with the anti-inflammatory, antimicrobial and choleretic action based on it.

Conflict of interest: authors have no conflict of interests to declare.

\section{REFERENCES}

1. Перспективи створення нових оригінальних препаратів на основі субстанцій рослинного походження / О. А. Рубан та ін. Фітотерапія. Часопис. 2012. № 2. С. 63-65.

2. Шостак Т. А., Калинюк Т. Г., Гудзь Н. І. Застосування рослинних субстанцій в якості активних фармацевтичних інгредієнтів. Фітотерапія. Часопис. 2014. № 3. С. 63-65.

3. Гонтова Т. М., Золотайкіна М. Ю. Перспективи вивчення вітчизняної сировини пижма звичайного. Актуальні питання розвитку медичних наук у XXI cm.: зб. матеріалів міжнар. наук.-практ. конф., м. Львів, 30-31 трав. 2014 р. Львів, 2014. С. 86-87.

4. Золотайкіна М. Ю., Сіра Л. М., Гонтова Т. М. Морфолого-анатомічні ознаки надземних органів пижма звичайного. Фармацевтичний часопис. 2016. № 1. С. 23-29. DOI: https://doi.org/10.11603/2312-0967.2016.1.6044.

5. Івасівка А. С., Гойванович Н. К. Аналіз антимікробних властивостей деяких лікарських рослин Передкарпаття. Науковий вісник НЛТУ Украӥни. 2015. Вип. 25.8. С. 169-174. DOI: https://doi.org/10.15421/40250828.

6. Кароматов И. Д., Абдувохидов А. Т. Применение пижмы в народной и научной медицине. Биология и интегративная медицина. 2018. № 9 (26). С. 72-83.

7. Державний реєстр лікарських засобів України. URL: http://www.drlz.kiev.ua/.

8. Компендіум online. URL: https://compendium.com.ua/uk/.

9. Державна фармакопея України / ДП «Український науковий фармакопейний центр якості лікарських засобів». 2-ге вид. Доповнення 2. Харків : ДП «Український науковий фармакопейний центр якості лікарських засобів», 2018. 336 с.

10. Розробка методики ідентифікації фенольних сполук у пижма квітках / М. Ю. Золотайкіна ін. ScienceRise: Pharmaceutical Science. 2016. T. 4, № 4 (21). C. 38-41. DOI: https://doi.org/10.15587/2313-8416.2016.67614.

11. Розробка методики кількісного визначення фенольних сполук у пижма квітках / М. Ю. Золотайкіна та ін. ScienceRise: Pharmaceutical Science. 2016. № 1 (1). C. 34-40. DOI: https://doi.org/10.15587/2519-4852.2016.72696. 


\section{REFERENCES}

1. Ruban, O. A., Malynovska, S. A., Al-Tovaiti, M., Mazurets, S. I. (2012). Fitoterapiia. Chasopys, 2, 63-65.

2. Shostak, T. A., Kalyniuk, T. H., Hudz, N. I. (2014). Fitoterapiia. Chasopys, 3, 63-65.

3. Hontova, T. M., Zolotaikina, M. Yu. (2014). Proceeding from Aktualni pytannia rozvytku medychnykh nauk u XXI st.: zb. materialiv mizhnar. nauk.-prakt. konf. (30-31 trav. 2014 r.). (pp. 86-87). Lviv.

4. Zolotaikina, M. Yu., Sira, L. M., Hontova, T. M. (2016). Farmatsevtychnyi chasopys, 1, 23-29. doi: https://doi.org/10.11603/23120967.2016.1.6044.

5. Ivasivka, A. S., Hoivanovych, N. K. (2015). Naukovyi visnyk NLTU Ukrainy, 25.8, 169-174. doi: https://doi.org/10.15421/40250828.

6. Karomatov, I. D., Abduvokhydov, A. T. (2018). Biolohiia i intehrativnaia meditsina, 9 (26), $72-83$.

7. Derzhavnyi reiestr likarskykh zasobiv Ukrainy. Available at: http://www.drlz.kiev.ua/.

8. Kompendium online. Available at: https://compendium.com.ua/uk/.

9. DP «Ukrainskyi naukovyi farmakopeinyi tsentr yakosti likarskykh zasobiv». (2018). Derzhavna Farmakopeia Ukrainy. Dopovnennia 2 (2nd ed.). Kharkiv: DP «Ukrainskyi naukovyi farmakopeinyi tsentr yakosti likarskykh zasobiv», 336.

10. Zolotaikina, M. Yu., Hontova, T. M., Kotova, E. E., Kotov, A. H., Hubar, S. M. (2016). ScienceRise: Pharmaceutical Science. 4 (21), 38-41. doi: https://doi.org/10.15587/2313-8416.2016.67614.

11. Zolotaikina, M. Yu., Hontova, T. M., Kotova, E. E., Kotov, A. H., Hubar, S. M. (2016). ScienceRise: Pharmaceutical Science, 1 (1), 34-40. DOI: https://doi.org/10.15587/2519-4852.2016.72696.

\section{Information about authors:}

Herbina N. A., Candidate of Pharmacy (Ph.D.), associate professor of the Department of Industrial Technology of Drugs, National University of Pharmacy of the Ministry of Health of Ukraine. E-mail: n.a.gerbina@gmail.com. ORCID: https://orcid.org/0000-0001-9826-7552

Ruban O. A., Doctor of Pharmacy (Dr. habil.), professor, head of the Department of Industrial Technology of Drugs, National University of Pharmacy of the Ministry of Health of Ukraine. E-mail: ztl@ukrfa.kharkov.ua. ORCID: https://orcid.org/0000-0002-2456-8210

Gontova T. M., Doctor of Pharmacy (Dr. habil.), professor, head of the Department of Botany, National University of Pharmacy of the Ministry of Health of Ukraine. E-mail: tetianaviola@ukr.net. ORCID: https://orcid.org/0000-0003-3941-9127

Yaremenko M. S., postgraduate student of the Department of Botany, National University of Pharmacy of the Ministry of Health of Ukraine. E-mail: caecys@gmail.com. ORCID: https://orcid.org/0000-0001-7736-0336

Yurchenko C. Yu., postgraduate student of the Clinical Pharmacology Department of Institute of Qualification Improvement for Pharmacists, National University of Pharmacy. E-mail: catherinyuyu@gmail.com. ORCID: https://orcid.org/0000-0003-3715-4225

Відомості про авторів:

Гербіна Н. А., кандидатка фармац. наук, доцентка кафедри заводської технології ліків, Національний фармацевтичний університет Міністерства охорони здоров’я України. E-mail: n.a.gerbina@gmail.com. ORCID: http://orcid.org/0000-0001-9826-7552

Рубан О. А., докторка фармац. наук, професорка, завідувачка кафедри заводської технології ліків, Національний фармацевтичний університет Міністерства охорони здоров’я України. E-mail: ruban_elen@ukr.net. ORCID: http://orcid.org/0000-0002-2456-8210 Гонтова Т. М., докторка фармац. наук, професорка, завідувачка кафедри ботаніки, Національний фармацевтичний університет Міністерства охорони здоров’я України. E-mail: tetianaviola@ukr.net ORCID: https://orcid.org/0000-0003-3941-9127

Яременко М. С., аспірант кафедри ботаніки, Національний фармацевтичний університет Міністерства охорони здоров'я України. E-mail: caecys@gmail.com. ORCID: https://orcid.org/0000-0001-7736-0336

Юрченко К. Ю., аспірантка кафедри клінічної фармакології, Інститут підвищення кваліфікації спеціалістів фармації Національного фармацевтичного університету Міністерства охорони здоров'я України. E-mail: catherinyuyu@gmail.com.

ORCID: https://orcid.org/0000-0003-3715-4225

Сведения об авторах:

Гербина Н. А., кандидат фармац. наук, доцент кафедры заводской технологии лекарств, Национальный фармацевтический университет Министерства здравоохранения Украины. E-mail: n.a.gerbina@gmail.com. ORCID: http://orcid.org/0000-0001-9826-7552 Рубан Е. А., доктор фармац. наук, профессор, заведующая кафедрой заводской технологии лекарств, Национальный фармацевтический университет Министерства здравоохранения Украины. E-mail: ruban_elen@ukr.net.

ORCID: http://orcid.org/0000-0002-2456-8210

Гонтовая Т. Н., доктор фармац. наук, профессор, заведущая кафедрой ботаники, Национальный фармацевтический университет Министерства здравоохранения Украины. E-mail: tetianaviola@ukr.net. ORCID: https://orcid.org/0000-0003-3941-9127

Яременко М. С., аспирант кафедры ботаники, Национальный фармацевтический университет Министерства здравоохранения Украины. E-mail: caecys@gmail.com. ORCID: https://orcid.org/0000-0001-7736-0336

Юрченко Е. Ю., аспирант кафедры клинической фармакологии, Институт повышения квалификации специалистов фармации Национального фармацевтического университета Министерства здравоохранения Украины. E-mail: catherinyuyu@gmail.com. ORCID: https://orcid.org/0000-0003-3715-4225 